\title{
A Cognitive Study on the Translation of Conceptual Metaphorical ESWIS - A Case Study of the Chinese Translation of 1984 by George Orwell
}

\author{
Ding Yue, Wu Biyu* \\ School of Foreign Languages, East China University of Science and Technology, China
}

Received February 27, 2020; Revised April 9, 2020; Accepted April 27, 2020

Copyright $\odot 2020$ by authors, all rights reserved. Authors agree that this article remains permanently open access under the terms of the Creative Commons Attribution License 4.0 International License

\begin{abstract}
Due to the differences in conscious tendencies of the relationship between human beings and objects, the habit of using inanimate subjects of Chinese and English speaker is different. English sentences with inanimate subjects (ESWIS) bring difficult ies for Chinese translation for it combines the usage of inanimate subjects and conceptual metaphors. This paper illustrates the usage of subjects and metaphors in ESWIS translation. It focuses on the interpretation of Conceptual Metaphorical ESWIS and makes analyses from the conceptual metaphor view. It is a case study which samples Conceptual Metaphorical ESWIS in the novel 1984 by George Orwell. It illustrates translation of Conceptual Metaphorical ESWIS with subjects "voice" "fear" "courage" "smile" in the whole corpus and explains translation decisions based on conceptual metaphors of this subjects. The research has two major findings: firstly, the universal existence of sentences with inanimate subjects in both Chinese and English can be explained either using direct description or through metaphors; Secondly, given the conscious tendencies of Chinese and English speakers in the relationship between human beings and objects, as well as how they use metaphors, the Chinese trans lation of ESWIS may use either animate subjects or inanimate subjects. It then subsequently may adopt the same or different conceptual metaphors compared with those in English, or just give direct descriptions to clarify the meanings. This paper provides practical and theoretical references for the translation of Conceptual Metaphorical ESWIS.
\end{abstract}

Keyword English Sentences with Inanimate Subjects (ESWIS), Inanimate Subject, Conceptual Metaphor, Translation, Cognitive Perspective, the Novel 1984

\section{Introduction}

Inanimate subjects are frequently used in English Sentences with Inanimate Subject (short for ESWIS). ESWIS refers to the sentences that use inanimate objects (such as real object and abstract conception) as Subjects and verbs describing material or psychological processes as Predicates (He Mingzhu, 2003: p51). The Chinese translation of ESWIS usually requires the conversion of sentence components. Based on animacy, ESWIS classify into two types of sentences - the structural type and the metaphorical type. The metaphorical type consists of Conceptual Metaphorical ESWIS and Grammatical Metaphorical ESWIS according to semantic features, as shown in Figure 1 and Table $1^{1}$ ( He Mingzhu,2005).

The collocation of Subject and Predicate or the embodiment of animacy in metaphorical ESWIS is different from that in the Chinese language. Based on the view of conceptual metaphor, this paper takes the text of the novel 1984 and Chinese translations by Dong Le'shan in 2003 (Year of publication) $^{2}$ and Liu Shao'ming in 2013 (Year of publication) $^{3}$ as the research corpus, so as to gain a deeper understanding of the Chinese translation of Conceptual Metaphorical ESWIS.

1 The English version of both Figure 1 and Table 1 is cited from reference [5] and translated by the author.

2 Nineteen Eighty-four, Trans. Dong Le'shan. Shanghai, Shanghai Translation Publishing House, 2003.

3 Nineteen Eighty-four, Trans. Liu Shao'ming, Beijing, Beijing Shiyue Literature and Art Press, 2013. 


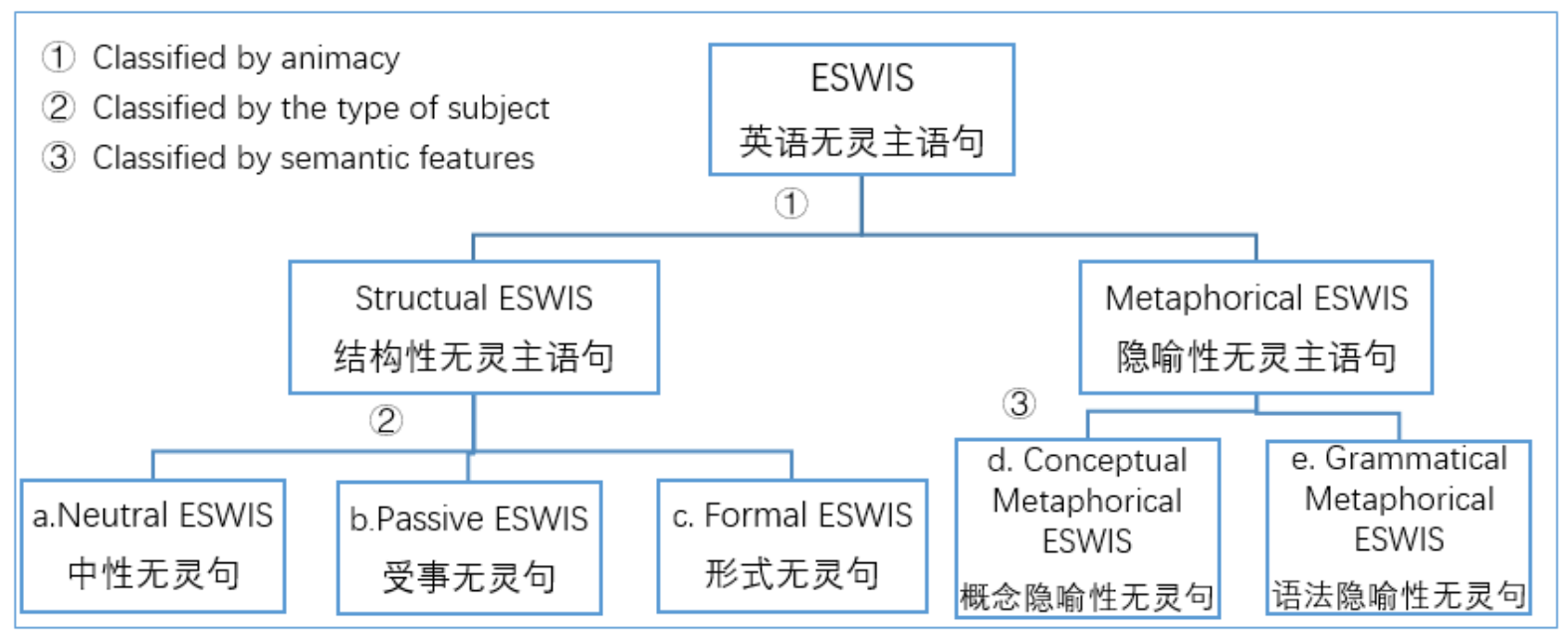

Figure 1. Classification of ESWIS

Table1. Examples for each type of ESWIS

\begin{tabular}{|c|c|c|}
\hline Classification & Structure & Example \\
\hline \multirow{4}{*}{ a.Neutral ESWIS } & S+link V+C & $\begin{array}{l}\text { Your ideal is unrealistic. } \\
\text { A spade and a rake are necessary tools for this work. }\end{array}$ \\
\hline & $\mathrm{S}+\mathrm{Vi}$ & $\begin{array}{l}\text { The rain stopped but the snow continued. } \\
\text { Traffic accidents frequently happen on this road }\end{array}$ \\
\hline & $\mathrm{S}+\mathrm{Vt}+\mathrm{O}$ & $\begin{array}{l}\text { The appointment slipped my memory. } \\
\text { Tract ors facilitate farming. }\end{array}$ \\
\hline & $\mathrm{S}+\mathrm{Vt}+\mathrm{O}(\mathrm{sb})$. & $\begin{array}{l}\text { Darkness frightens children. } \\
\text { His answer puzzled me. }\end{array}$ \\
\hline b.Passive ESWIS & N/A & $\begin{array}{l}\text { The plan will soon be examined. } \\
\text { Theyellow leaves were scattered every where in the aut umn wind. }\end{array}$ \\
\hline \multirow{6}{*}{ c.Formal ESWIS } & $\begin{array}{l}\text { Inanimate pronoun "it" as } \\
\text { Subject }\end{array}$ & $\begin{array}{l}\text { It is six o'clock now, it is clearing up and it is quiet everywhere. } \\
\text { It is going to be an increased satisfaction to our customers if we } \\
\text { are happy. }\end{array}$ \\
\hline & $\mathrm{It}+\mathrm{V}+\mathrm{to}$ do sth. & $\begin{array}{l}\text { It gives me pleasure to confide a little in you. } \\
\text { It is his fate to leave here in evening. }\end{array}$ \\
\hline & $\mathrm{It}+\mathrm{V}+$ doing sth. & $\begin{array}{l}\text { It is no use crying over spilled milk. } \\
\text { It does not make any difference my being there. }\end{array}$ \\
\hline & $\mathrm{It}+\mathrm{V}+\mathrm{th}$ at $($ wh)-clause & $\begin{array}{l}\text { It is reported that the president will visit Canada in June. } \\
\text { It does not matter whether he attends the meeting or not. }\end{array}$ \\
\hline & Emphatic structure of "it" & It was John who met your sister in the zoo yesterday. \\
\hline & There+be & There were staring eyes and dropping jaws all around us. \\
\hline $\begin{array}{ll}\text { d.Conceptual } & \text { Metaphorical } \\
\text { ESWIS } & \\
\end{array}$ & N/A & $\begin{array}{l}\text { A good idea suddenly struck me. } \\
\text { Dusk found the child crying in the street. }\end{array}$ \\
\hline $\begin{array}{l}\text { e.Grammatical Metaphorical } \\
\text { ESWIS }\end{array}$ & N/A & $\begin{array}{l}\text { The execution of the prisoner preceded the president's arrival. } \\
\text { The visibility of his impatience was very great. }\end{array}$ \\
\hline
\end{tabular}

\section{Literature Review}

\subsection{Cognitive Perspective on Metaphor Translation}

In the narrow sense, Cognitive Linguistics is an interdisciplinary branch of cognitive sciences that adheres to the experience philosophy by focusing on the study of conceptual structure and semantics based on physical experience and cognition to make unified interpretation of language with cognitive mode and knowledge structure (Wang Yin, 2006: p11). The meanings of language form through different cognitive styles: Lexical meanings are the generalization of a kind of object by concepts, for which the cognitive modes mainly involve survey, classification, conceptualization, and categorization. Grammar is the rules abstracted from the units of the same kind of words, phrases and sentences by the modes of abstraction and conduction. Lastly, the Rhetorical meaning, which is dialectically united with lexical meaning, is the emotional meaning of linguistic units. This rhetorical mean ing reflects people's subjective feelings, attitudes and evaluations of objects by the cognitive modes including concretization, visualization, metaphor and association (Wang De'chun, 2009:p.28). Metaphors play a pivotal role 
in the cognition movement from abstract to a concrete.

Research on metaphor has a long history. In the beginning, the metaphor was merely regarded as a rhetorical figure of speech. This attitude has changed. Currently, it has been viewed as a cognitive model and reasoning mechanism as well. One of the theories that plays a major role in metaphors studies is Conceptual Metaphor Theory (CMT) proposed by Lakoff \&Johns on in 1980. The core of this theory is the cross-domain mapping principle. Lakoff believes that metaphor is a mode of thought "defined by a systematic mapping from a source to a target domain" (Lakoff. G, 1992: p.7). The conceptual metaphor "LIFE IS A JOURNEY" sets "JOURNEY" as a source domain and "LIFE" as a target domain. Lakoff points that metaphors are mappings across conceptual domains and such mappings are not arb itrary, but grounded in the body and in everyday experience and knowledge (Lakoff, G, 1992:40).

Since the 1980s, the interdiscip linary study of metaphor has flourished. Halliday proposed a "Grammatical Metaphor" in the framework of functional grammar (Halliday, 1994: p342) - metaphor not only exists in the lexical layer but also occurs in the syntax layer. The main form of conceptual function in English is the transitivity system. Halliday's transitive system theory holds that human activities in the subjective and objective world are described in six processes - in material, psychology, relationship, speech, behavior, and existence, all of which can be metaphorized into each other. Moreover, nominalization is one approach of speech transformation for the metaphor of processes.

Translation involves the semantic connection between languages and cultures. Cognitive structure, culture, and background knowledge influence the translation of metaphor. The similarity mapping conditions on the network of emotional, conceptual metaphors are the bas is for the translatability of metaphor (Tan Ye'sheng \& Ge
Jinrong, 2005:60). Many studies focus on the translation of metaphors in specific fields such as finance, law, traditional Chinese medicine etc.

\subsection{Cognitive Perspective on Metaphorical ESWIS}

Based on the "Conceptual Metaphor Theory" of Lakoff and the "Grammatical Metaphor Theory" of Halliday, He Mingzhu (2005) classified metaphorical ESWIS into Conceptual Metaphorical ESWIS and Grammatical Metaphorical ESWIS (see Figure 1 and Table 1): the first type is composed by inanimate subject and animate predicate, where the cognitive domain of animate predicate projects (or maps) to the inanimate cognitive domain of the subject, enabling inanimate things or concepts to have semantic features of life, and then generate conceptual metaphor, equal to personification figures of speech in traditional rhetoric; the second type is formed through nominalization - to transform the whole clause structure including verbs and adjectives into nouns or noun phrases, and the process or attribute are embodied as participants (He Mingzhu, 2005: p89,12). Weng Yi'ming (2005), Sun Rui (2008) and other researchers analyzed the generation mechanism of ESWIS in the view of metaphor.

The translation strategies of the two kinds of metaphorical ESWIS should be different: Conceptual metaphorical ESWIS itself can be regarded as a rhetorical device to achieve the aesthetic effect; For grammatical metaphorical ESWIS, it is the semantic functions, not aesthetic effects that the sentence aims to gain (He Mingzhu, 2003: p53). He Mingzhu pointed out that the subject of the Chinese translation version (such as the subject of personal pronoun or noun, the subject of the general term "people" and the non-subject) should first be established for the translation of the Conceptual Metaphorical ESWIS (see Table 2).

Table 2. Examples of Translation on Conceptual Metaphorical ESWIS

\begin{tabular}{|l|l|l|}
\hline Original sentence & Chinese translation and its literaltranslation in English & $\begin{array}{l}\text { The Subject of Chinese } \\
\text { translation }\end{array}$ \\
\hline 1. Pork has priced it self out of his dish. & $\begin{array}{l}\text { 猪肉太贵, 他吃不起。 } \\
\text { Pork is so expensive. He can't afford it. (or: (Because) } \\
\text { pork is so expensive, he can't affordit.) }\end{array}$ & $\begin{array}{l}\text { The personal Possessive Case in } \\
\text { the original sentence }\end{array}$ \\
\hline $\begin{array}{l}\text { 2. Space does not allow us to further } \\
\text { analyze this problem here. }\end{array}$ & $\begin{array}{l}\text { 限于篇幅, 我们不能在此对这个问题作进一步分析。 } \\
\text { Limited by the space, we can't further analyze this } \\
\text { problem here. }\end{array}$ & $\begin{array}{l}\text { The personal object in the } \\
\text { original sentence }\end{array}$ \\
\hline $\begin{array}{l}\text { 3. By now optimism had given way to } \\
\text { doubt. }\end{array}$ & $\begin{array}{l}\text { 至此, 人们不再盲目乐观, 而是疑惑重重。 } \\
\text { Bynow, people hadno optimism anymore but doubt. }\end{array}$ & A general term “people” \\
\hline $\begin{array}{l}\text { 4. Adversity and struggle lie at the roots } \\
\text { of evolutionary progress. }\end{array}$ & $\begin{array}{l}\text { 逆境和奋斗是进化语发展的根源。 } \\
\text { Adversity and struggle are the roots of evolutionary } \\
\text { progress. }\end{array}$ & $\begin{array}{l}\text { A subject in the original } \\
\text { sentences }\end{array}$ \\
\hline
\end{tabular}


Sun Xingwen (2006) and other researchers explained the formation mechanism and translation strategies of metaphorical ESWIS. However, room there still exists for the investigation of the translation process from the perspective of cross-language metaphor. He Mingzhu (2011) mentioned that "the predicates in Conceptual Metaphorical ESWIS used for rhetorical effects are usually omitted in the translation, while their rhetorical effects can be compensated in other ways in the target text". The author believes for the interpretation of Conceptual Metaphor, the target text may still preserve the rhetorical effects as the original text, and that possibilities are worth discussing.

Accordingly, rhetoric devices in the traditional language sense are a linguistic embodiment of metaphor cognition. The conceptual metaphor and grammatical metaphor form ESWIS, and Chinese inanimate sentences may also be formed through metaphor. The universal cognitive mode based on metaphor naturally produce inanimate sentences both in English and in Chinese, and therefore translating ESWIS into Chinese inanimate sentences is also accepted by Chinese native speakers. It is reasonable to study the translation of ESWIS into Chinese based on the shared points of Chinese and English metaphor modes. The following section will illustrate the interpretation of Conceptual Metaphorical ESWIS.

\section{Research Design}

\subsection{Material and Methodology}

Literary works enjoy vast popularity of all genres and ESWIS add vividness in literary works. George Orwell (1903-1950) was a famous writer known in the world. His novel 1984, as one of the most influential English-language novels of the $20^{\text {th }}$ century, has been translated into more than 60 languages and sold over 30 million copies world wide. It has 14 published versions in Chinese from the year 1979 to 2012 .

This paper is a case study of the Chinese translation of Conceptual Metaphorical ESWIS in the novel 1984. It selects the original text from the novel 1984 by George Orwell (with 105,309 words in total) and two Chinese translations by Dong Le'shan in 2003 and Liu Shao'ming in 2013 (with 356,000 characters in total). The author uses AntConc to search for the appropriate systematic corpus with the selected head words. The two steps are: 1) retrieving nouns related to physical experience (such as "voice" which is an important surroundings ele ment of the protagonist, "smile" the physical action, "fear" the abstract emotions of human being and "courage" the spiritual quality of human being) from 1984 text; and 2) analyzing the examples where the selected word appears in ESWIS.

\subsection{Research Questions}

There are three questions about the Chinese translation of Conceptual Metaphorical ESWIS in this research. First, whether the inanimate subjects in the original sentences are maintained? Second, how to deal with the metaphorical part in the source text? Third, what are the cognitive similarities and differences between English and Chinese language that the translation process illustrates?

\section{Results and Discussion}

Corpus retrieval results show that objective things "voice" and abstract emotion "fear" and other words without life features as inanimate subjects are quite frequent. It reflects the living surroundings and psychological state of "thought criminal" in the novel 1984 - the voices - the telescreen radio voice, singing sound, street people, the figures' voice are important environmental elements. In the following Chinese translation sentences, $\mathrm{T} 1$ and $\mathrm{T} 2$ are the translation from Dong Le'shan and Liu Shao'ming, and each LT stands for literary translation of Chinese sentence.

\subsection{Translation of Conceptual Metaphorical ESWIS with "Voice" as Subject}

The word frequency of "voice (the sound or sounds produced through the mouth by a person)" is 114 , in which the noun form is used as the subject for 37 times, of which there are three kinds of words: the first are verbs that manifest the situation of non-life things, including "come from, continue, change, pause, stop, repeat"; the second includes "cry, call, sing, say, yap, yell, scream, utter, babble away", which are often used to refer to people or vocalizations, to describe the single behavior of "making a sound", and to form metaphorical sentences, such as Eg. (1); the third are other verbs that do not merely describe the action of "making a sound" to form ESWIS from conceptual metaphor, as shown in Table 3.

Eg. (1): Inside the flat, a fruity voice was reading out a list of figures which had something to do with the production of pig-iron.

$\mathrm{T} 1$ :在他住所里面, 有个圆润的嗓子在念一系列与生 铁产量有关的数字。

TL: In his lodgings a round throat was reading out a list of figures....

$\mathrm{T} 2$ :温斯顿一踏入自己的房间, 就听到一个运腔圆润 的声音, 正在一板一眼地念着大概是与生铁生产有关 的数字。

TL: As soon as Winston entered his room, he heard a round voice reading out a list of figures....

The quality of "sound" in Chinese is describable, but the sound has no subjective initiative and cannot be matched with “念, to read” alone. T1 uses inanimate subjects “嗓子, throat". There is a change in perspective from the result (voice) to the tool (throat). Also, compared with "voice", “嗓子, throat” as an organ for making voice is more subjective initiative. Ho wever, the subject-verb collocation 
of T1 “嗓子+念 (voice + read)" is rarely seen in Chinese. Chinese sentences like “有人在念东西 Someone is reading sth.(people + read )", “有人扯着嗓子在念东西 Someone is reading sth. at the top of his/her voice" “有人 捏着嗓子念东西 Someone is pinching his/her throat as he/her reads sth.” are frequent but the sentence “有个嗓子 在念东西 A throat is reading sth." is rarely used. T2 takes personal subject, using the sensory verb “听到, to hear.”
Sensory verbs are primarily used to indicate the connection between subject and object (Levin. B, 1993: p185). Fluency is the primary translation standard and to make the translation sentences fluent is the prerequisite of reflecting the aesthetic style of languages. (Wang Jianguo \& Zhang Hong, 2016). For this Example, T2 uses the sensory verb (heard) and personal subject "he", thus gaining more fluency than T1.

Table 3. Translation of Conceptual Metaphorical ESWIS with "voice" as Subject

\begin{tabular}{|c|c|c|c|}
\hline $\begin{array}{l}\text { Eg. } \\
\text { (No.) }\end{array}$ & Source Text & Target Text & $\begin{array}{l}\text { Literal Translation of the Underlined Part in } \\
\text { Target Text }\end{array}$ \\
\hline \multirow{2}{*}{ (1) } & \multirow{2}{*}{$\begin{array}{l}\text { Winst on turned a switch and the voice } \\
\text { sank somewhat, though the words were } \\
\text { still distinguishable. }\end{array}$} & $\begin{array}{l}\text { T1:温斯顿按了一个开关, 声音 } \\
\text { 就了一些, 不过说的话仍听 } \\
\text { 得清楚。 }\end{array}$ & $\begin{array}{l}\text { Winst on turned a switch and the voice became } \\
\text { light somewhat, though.... }\end{array}$ \\
\hline & & $\begin{array}{l}\text { T2: 温斯顿调节了一下开关, } \\
\text { 声音低下来, 但生产数字仍 } \\
\text { 清晰可闻。 }\end{array}$ & $\begin{array}{l}\text { Winst on turned a switch and the voice lowered } \\
\text { somewhat, though... }\end{array}$ \\
\hline \multirow{2}{*}{ (2) } & \multirow{2}{*}{$\begin{array}{l}\text { His voice had grown almost dreamy.... } \\
\text { His voice had grown stern again. }\end{array}$} & $\begin{array}{l}\text { T1: 他的声音几乎有了一种梦 } \\
\text { 境的味道。……他的声音又严 } \\
\text { 厉起来了。 }\end{array}$ & $\begin{array}{l}\text { His voice almost had had a flavor of a dream.... } \\
\text { His voice had gotten stern again. }\end{array}$ \\
\hline & & $\begin{array}{l}\text { T2: 奥布赖恩的声音变得有点 } \\
\text { 如醉如痴, .......奥布赖恩...... } \\
\text { 声音又变得冷峻起来。 } \\
\end{array}$ & $\begin{array}{l}\text { O'Brien's voice had become almost dreamy.... } \\
\text { O'Brien's voice had become stern again. }\end{array}$ \\
\hline \multirow[b]{2}{*}{ (3) } & \multirow{2}{*}{$\begin{array}{l}\text { As usual, the voice had battered } \\
\text { Winston into helplessness. }\end{array}$} & $\begin{array}{l}\text { T1:像刚才一样,一番话把温斯 } \\
\text { 顿说得哑口无言。 }\end{array}$ & $\begin{array}{l}\text { As just now, a few words had made Winston } \\
\text { speechless. }\end{array}$ \\
\hline & & $\begin{array}{l}\text { T2: 正如他预料的一样, 奥布 } \\
\text { 赖恩的逻辑使他毫无反击之 } \\
\text { 力。 }\end{array}$ & $\begin{array}{l}\text { As he expected, O'Brien's logic had made him } \\
\text { have no counterattacking power. }\end{array}$ \\
\hline \multirow[t]{2}{*}{ (4) } & \multirow{2}{*}{$\begin{array}{l}\text { In the end the nagging voices broke him } \\
\text { down more completely than the boots } \\
\text { and fists of the guards. }\end{array}$} & $\begin{array}{l}\text { T1: 终于这种喋喋不休的盘问 } \\
\text { 比警卫的拳打脚踢还要奏效, } \\
\text { 使他完全屈服。 }\end{array}$ & $\begin{array}{l}\text { In the end the nagging voices turned more } \\
\text { efficiently than the boots and fists of the guards, } \\
\text { which made him to completely submit. }\end{array}$ \\
\hline & & $\begin{array}{l}\mathrm{T} 2 \text { :疲劳审讯的方式果然比黑 } \\
\text { 衣汉子的拳脚有效。 }\end{array}$ & $\begin{array}{l}\text { The fat igue interrogation turned more efficiently } \\
\text { than the boots and fists of the guards }\end{array}$ \\
\hline \multirow[b]{2}{*}{ (5) } & \multirow{2}{*}{$\begin{array}{l}\text { Always the eyes watching you and the } \\
\text { voice enveloping you. }\end{array}$} & $\begin{array}{l}\text { T1: 眼光总是盯着你, 声音总 } \\
\text { 是在你的耳边响着。 }\end{array}$ & $\begin{array}{l}\text { Always the eyes were watching you and the } \\
\text { voice ringing around your eyes. }\end{array}$ \\
\hline & & $\begin{array}{l}\text { T2: 他的眼睛看管着你, 声音 } \\
\text { 包围你。 }\end{array}$ & $\begin{array}{l}\text { His eyes were watching you and his voice } \\
\text { surrounding you. }\end{array}$ \\
\hline \multirow{2}{*}{ (6) } & \multirow{2}{*}{$\begin{array}{l}\text { Her voice seemed to stick into his brain } \\
\text { like jagged splinters of glass. }\end{array}$} & $\begin{array}{l}\text { T1: 她的声音好像碎玻璃片一 } \\
\text { 样刺进他的脑海。 }\end{array}$ & $\begin{array}{l}\text { Her voice seemed to stick into his brain like } \\
\text { jagged splinters of glass. }\end{array}$ \\
\hline & & $\begin{array}{l}\text { T2: 她的声音好像玻璃片一样 } \\
\text { 扎在他脑海中。 }\end{array}$ & Her voice stuck in his head like glass. \\
\hline \multirow{2}{*}{ (7) } & \multirow{2}{*}{$\begin{array}{l}\text { Her voice floated upward with the sweet } \\
\text { summer air. }\end{array}$} & $\begin{array}{l}\text { T1: 她的歌声随着夏天的甜美 } \\
\text { 空气飘了上来。 }\end{array}$ & Her song floated up in the sweet summer air. \\
\hline & & $\begin{array}{l}\text { T2: 她的歌声随着六月甜润的 } \\
\text { 空气飘荡。 }\end{array}$ & Her song floated in the sweet June air. \\
\hline
\end{tabular}


Given the universal similarity of human experience, shared metaphors exist in different languages, but experience involves multiple factors such as physical, cultural and social factors. These factors can explain the differences in conceptual metaphors in different cultures. In Eg. (1)-(5) in Table 3, the verbal metaphor matching with "voice" in Chinese is different from that in English, which to some extent reflects the different cognitive modes of English and Chinese language users.

In Eg.(1) in Table 3., "sink" refers to the "to go down below the surface or towards the bottom of a liquid or soft substance", a movement of tangible things. With the combination of "voice", the verb "sink" turns abstraction into concrete scenario, see Eg.(1). However, the collocation of “声音十下沉, (sound + sink)” is rarely used in Chinese. $\mathrm{T} 1$ and T2 use adjectives to transform verbs - "轻, light" and “低, low", which all directly describe the quality of sound.

Eg. (1): Her voice sank to a whisper.她的声音变成了耳 语(LT: Her voice sank to a whisper)。(Oxford Dictionary)

In Eg. (2) the meaning of the word "grow" is mapped from the natural growth of simple plants and animals to the definition of "making progress" and "changing" of abstract things, see Eg(2). The Chinese word “生长, to grow" is often used in the description of living things or as a metaphor for concrete objects. The translation here adopts the extended meaning.

Eg.(2): The skies grew dark and it began to rain. 天渐渐 黑了, 又下起雨来(LT: The skies gradually darkened and again began the rain). (Oxford Dictionary)
The predicates “batter (连续猛击、殴打)” in Eg. (3), “break down(分解、砸到)” in Eg. (4) and “envelop (包住、 裹住)" in Eg. (5) e mbody the metaphor that "the sound is force”. In Eg. (3) the trans lations use “把 (bă) construction” 4 and “使 ( $\mathrm{sh} \check{1}$ ) construction" 5 respectively. The comparative structure is used in the original text in Eg. (4). T1 uses the comparative structure while using the verb structure, while T2 does not translate the verbal metaphor of the original text, but directly implies its meaning in the comparative structure. In Eg. (5), the verb “响, to make sound" used in T1 directly describes the objective environment where sound exists everywhere.- In Chinese, there are similar metaphorical cognitive scenes of “声音+ 包围+某物或人, sound + surround + something or pers on”, but rare expressions of "sound + surround + something or person". Therefore, the verbal metaphor in the original te xt is in a vague state between translatable and untrans latable.

Eg. (6) and Eg. (7) shows the same conceptual metaphor mapping in Eng lish language and Chinese language as their Chinese translation uses the same inanimate subjects and the same conceptualmetaphor as those in English.

\subsection{Translation of Conceptual Metaphorical ESWIS with "Fear" as Subject}

There are differences between Chinese and English in the emotional metaphor of the shared physiological experience. In the text, the word "fear" appears 37 times, including 32 times of noun use, 4 times of verb use and 1 time of adjective form use ("fearless"). Among them, 8 times of "fear" is used as the subject of Conceptual Metaphorical ESWIS, as shown in Table 4. 
Table 4. Translation of Conceptual Metaphorical ESWIS with "fear" as Subject

\begin{tabular}{|c|c|c|c|}
\hline $\begin{array}{l}\text { Fg. } \\
\text { (No.) }\end{array}$ & Source Text & Target Text & $\begin{array}{l}\text { Literal Translation of the Underlined } \\
\text { Part in Target Text }\end{array}$ \\
\hline \multirow{2}{*}{ (8) } & \multirow{2}{*}{$\begin{array}{l}\text { It was all-important to speak at once, before } \\
\text { anyone else came, but now a terrible fear had } \\
\text { taken possession of him. }\end{array}$} & $\begin{array}{l}\text { T1: 应该趁还没有人到来以 } \\
\text { 前马上说话, 但是他忽然一阵 } \\
\text { 疑惧袭心。 }\end{array}$ & $\begin{array}{l}\text {...but now he suddenly (had felt) a fit of } \\
\text { fear attaching heart. }\end{array}$ \\
\hline & & $\begin{array}{l}\text { T2: 当务之急就是马上跟她 } \\
\text { 说话, 否则别人就坐到旁边 } \\
\text { 了。可是他实在担心得很。 }\end{array}$ & ...but now he had been really worried. \\
\hline \multirow{2}{*}{ (9) } & \multirow{2}{*}{$\begin{array}{l}\text { A twinge of fear went through him. It had been } \\
\text { a sufficiently rash act to buy the book in the } \\
\text { beginning, and he had sworn never to come } \\
\text { near the place again. }\end{array}$} & $\begin{array}{l}\text { T1: 他心中感到一阵恐慌。当 } \\
\text { 初买那本日记本, 本来是件够 } \\
\text { 冒失的事, 他心中曾发誓再也 } \\
\text { 不到这个地方来。 }\end{array}$ & $\begin{array}{l}\text { He felt a twinge of fear. It had been a } \\
\text { sufficiently rash act.... }\end{array}$ \\
\hline & & $\begin{array}{l}\text { T2; 此时他有点害怕起来。到 } \\
\text { 这儿来买那本簿子已是冒险 } \\
\text { 不过的事, 自己不是发过誓永 } \\
\text { 不涉足此地吗? }\end{array}$ & $\begin{array}{l}\text { He felt a little scared. It had been a } \\
\text { sufficiently rash act.... }\end{array}$ \\
\hline \multirow{2}{*}{$(10)$} & \multirow{2}{*}{ Again the terrible fear seized upon Winston. } & $\begin{array}{l}\text { T1: 温斯顿心中又是一阵疑 } \\
\text { 惧。 }\end{array}$ & $\begin{array}{l}\text { Winst on in the heart (felt) another fit of } \\
\text { fear. }\end{array}$ \\
\hline & & T2: 温斯顿不觉又担心起来。 & $\begin{array}{l}\text { Winst on unconsciously began to worry } \\
\text { again. }\end{array}$ \\
\hline \multirow{2}{*}{ (11) } & \multirow{2}{*}{$\begin{array}{l}\text { A sort of premonitory tremor, a fear of he was } \\
\text { not certain what, had passed through Winston } \\
\text { as soon as he caught his first glimpse of the } \\
\text { cage. }\end{array}$} & $\begin{array}{l}\text { T1: 温斯顿当初一看到那铁 } \\
\text { 笼子, 全身就有预感似的感到 } \\
\text { 一阵震颤, 一种莫名的恐惧。 }\end{array}$ & $\begin{array}{l}\text { Winston's whole body prophetically felt a } \\
\text { fit of tremor, an inexplicable fear as soon } \\
\text { as.... }\end{array}$ \\
\hline & & $\begin{array}{l}\text { T2: 温斯顿初见笼子时, 心中 } \\
\text { 就有恐怖的预感, 全身一阵震 } \\
\text { 颤。 }\end{array}$ & $\begin{array}{l}\text { Winst on in the heart had (felt) a foreboding } \\
\text { of fear and his whole body tremored as soon } \\
\text { as.... }\end{array}$ \\
\hline \multirow[t]{2}{*}{ (12) } & \multirow{2}{*}{$\begin{array}{l}\text { Then everything was normal again, and the old } \\
\text { fear, the hatred, and the bewilderment came } \\
\text { crowding back again. }\end{array}$} & $\begin{array}{l}\text { T1: 接着一切恢复正常, 原来 } \\
\text { 的恐惧、仇恨、迷惑又袭上心 } \\
\text { 来。 }\end{array}$ & $\begin{array}{l}\text { Then everything was normal again, and the } \\
\text { old fear, the hatred, and the bewilderment } \\
\text { attacked the heart again. }\end{array}$ \\
\hline & & $\begin{array}{l}\text { T2: 正常的心情—恐惧、仇 } \\
\text { 恨与迷茫，复现心头。 }\end{array}$ & $\begin{array}{l}\text { Normalmoods - the fear, the hatred and the } \\
\text { bewilderment reappeared in the heart. }\end{array}$ \\
\hline \multirow{2}{*}{ (13) } & \multirow{2}{*}{$\begin{array}{l}\text { The sealed world in which he lives would be } \\
\text { broken, and the fear, hatred, and } \\
\text { self-righteousness on which his morale depends } \\
\text { might evaporate. }\end{array}$} & $\begin{array}{l}\text { T1: 他所生活的封闭天地就 } \\
\text { 会打破, 他的精神所依的恐 } \\
\text { 惧、仇恨、自以为是就会化为 } \\
\text { 乌有。 }\end{array}$ & $\begin{array}{l}\text {...and the fear, hatred, and } \\
\text { self-righteousness on which his morale } \\
\text { depends might vanish. }\end{array}$ \\
\hline & & $\begin{array}{l}\text { T2: 这样, 他们久居的封闭世 } \\
\text { 界开了洞口, 而他们赖以支持 } \\
\text { 自己士气的恐惧、仇恨和自以 } \\
\text { 为是的道德感就瓦解了。 }\end{array}$ & $\begin{array}{l}\text {...and the fear, hatred, and } \\
\text { self-righteousness on which his morale } \\
\text { depends might collapse. }\end{array}$ \\
\hline \multirow[t]{2}{*}{ (14) } & \multirow{2}{*}{$\begin{array}{l}\text { A violent emotion, not fear exactly but a sort of } \\
\text { undifferentiated excitement, flared up in him, } \\
\text { then faded again. }\end{array}$} & $\begin{array}{l}\text { T1: 他心中忽然感到一阵激 } \\
\text { 动, 很难说是恐惧, 这是一种 } \\
\text { 莫名的激动, 但马上又平息下 } \\
\text { 去了。 }\end{array}$ & $\begin{array}{l}\text { He suddenly felt afit of excitement, not fear } \\
\text { exactly but a sort of undifferentiated } \\
\text { excitement thenfaded again. }\end{array}$ \\
\hline & & $\begin{array}{l}\text { T2: 一种无以名之的强烈感 } \\
\text { 情涌上心头, 但不久又冷下来 } \\
\text { 了。 }\end{array}$ & $\begin{array}{l}\text { An indescribably strong feeling surged up } \\
\text { the heart, but soon grew cold again }\end{array}$ \\
\hline \multirow{2}{*}{$(15)$} & \multirow{2}{*}{$\begin{array}{l}\text { A hideous ecstasy of fear and vindictiveness, a } \\
\text { desire to kill, to torture, to smash faces in with a } \\
\text { sledgehammer, seemed to flow through the } \\
\text { whole group of people like an electric current, } \\
\text { turning one even against one's will into a } \\
\text { grimacing, screaming lunatic. }\end{array}$} & $\begin{array}{l}\text { T1:一种夹杂着恐惧和报复 } \\
\text { 情绪的快意, 一种要杀人、虐 } \\
\text { 待、用大铁锤痛打别人脸孔的 } \\
\text { 欲望, 似乎像一股电流一般穿 } \\
\text { 过了这一群人, 甚至使你违反 } \\
\text { 本意地变成一个恶声叫喊的 } \\
\text { 疯子。 }\end{array}$ & $\begin{array}{l}\text {...seemed to flow through the whole group } \\
\text { of people like an electric current, turning } \\
\text { one even against one's will into a } \\
\text { grimacing, screaming lunatic. }\end{array}$ \\
\hline & & $\begin{array}{l}\text { T2: 任何一个观众这时都有 } \\
\text { 冲动要杀人、用刑折磨人, 或 } \\
\text { 用大锤把敌人的脑袋打得稀 } \\
\text { 烂。每个人都会像触电一般受 } \\
\text { 到这种激昂情绪所左右, 意志 } \\
\text { 力完全松解, 变成面目狰狞、 } \\
\text { 狂呼乱舞的疯子。 } \\
\end{array}$ & $\begin{array}{l}\text { Every audience now had a desire to kill, to } \\
\text { torture, to smash heads in with a } \\
\text { sledgehammer. Everyone seemed to be } \\
\text { electrocuted by this excitement, and to } \\
\text { become a grimacing, screaming lunatic } \\
\text { with willpower totally relaxed. }\end{array}$ \\
\hline
\end{tabular}


Similar or different mapping conditions (i.e. cognitive constraints) based on the metaphorical concept mapping system can not only explain the essence of different potential translation strategies, but also effectively define the potential space of translatability or untranslatability (Tan Ye'sheng, 2005: p62). The shared emotional conceptual metaphor in English and Chinese languages provides similar mapping conditions and the bas is for the translatability of metaphor.

In Eg. (8)-(11), go through (“经过”) and pass through (“穿过”) symbolized the process of physical movement. At the same time, seize (“抓住”) and take possession of (“占 有”) are behaviors of human beings and other living things, which are also movements in essence. The usage of these verbs has a rhetorical effect. If the translation has "fear". All translations (except T1 in Example (8)) take the Person “他 (he)" or "Winston" as the subject of the sentence, forming the structure of “人 (+心里) + 感到 + 恐惧, someone $(+$ in the heart $)+$ feels + fear". Here both the inanimate subject and the original metaphor are canceled in the translation.

In addition, in example (8), the sentence “他忽然一阵疑 惧袭心, he suddenly (had felt) a fit of fear attaching heart" in T1 begins with the personal subject “他(he)” and uses the four-character of “疑惧袭心(fear attaching heart)". In some circumstances, the use of Chinese four-character structure enables the translation to be consistent with ESWIS in tone, wording and writing style (He Ming zhu, 2003: p54).

The inanimate subject "fear" is preserved in T2s of Eg. (12), (13), and (14).

The predicate in translation “又袭上心来, attacked the heart again" and “复现, reappeared” is not equal to the original predicate come back (“回来”) which expresses the movement process in example (13). Metaphorical expressions in English and Chinese may be different although they are based on the same conceptual metaphors. $\mathrm{T} 1$ is smoother than T2 with better rhetorical effect.

Metaphorical expression relies on fundamental conceptual mapping. The predicate evaporate (“蒸发、挥 发, vaporization”) in Example (13) and flare up (“突然燃 烧, sudden combustion") in (14), both reflect the conceptual mapping "the emotion of fear is visible substance". The relationship between "vaporization" and "sudden combustion" and the objective substance and the state of the fear emotion is represented as "a liquid: emotion of fear = evaporation: disappearance" and "fuel: fear emotion = a combustible material: intense reaction".

The difference of concept mapping determines the untranslatability, so metaphor is cancelled in translation, or another approach is adopted, that is, to use the corresponding expression based on a shared conceptual metaphor, or construct expression based on specific conceptual metaphor in the target language culture (Tan Ye'sheng, 2005: p61). Translations in Example (13) remains the inanimate subject and uses predicate “(化为乌 有, vanish)” “(瓦解, collapse)” corresponding to evaporate to clarify the concept mapping.

In Example (14), "the violent emotion...flared up" means "the emotion burst out" in English. The T2 in example (14) which uses predicate “(涌上, surge up)" corresponding to flare up, conforms to the metaphor habit in Chinese. The usage of “涌上, surge up” instead of “突然 燃烧, burn suddenly" reflects the difference in conceptual mapping between English and Chinese based on the shared conceptual metaphor.(see Table 5.) The T1 in example (14) “他心中忽然感到一阵激动 He suddenly felt a fit of excitement" is a direct description of the metaphor.

Table 5. Differences of conceptual mapping of "emotion" in Eg (14)

\begin{tabular}{|c|c|c|c|}
\hline & Sentence & Conceptual metaphor & A difference in conceptual mapping \\
\hline Source Text & The emotion flared up & \multirow{2}{*}{ EMOTION IS A SUBST ANCE. } & Emotion is a combustible material. \\
T2 & The emotion surged up & & Emotion is liquid. \\
\hline
\end{tabular}


The T1 in Example (15) uses the inanimate subject “一 种夹杂着恐惧和报复情绪的快意 a sense of satisfaction mixed with fear and revenge" and remains the rhetoric expression "the electricity". T2 uses personal subjects “任 何一个观众, any audience” and “每个人, everyone”, and the rhetoric expression “像触电一般受到这种激昂情绪 所左右, be electrocuted by this excitement". Both versions express the metaphor that "ecstasy of fear and other emotion is electric current", but T2 is easier to understand.

\subsection{Other ESWISs from Conceptual Metaphor}

Language reflects the actual events and scenes through cognitive construction and expression. In the generation and understanding of language, the content that the language itself activates is incomplete. It is the additional background knowledge that language users leverage, consciously or unconsciously, to connect clips of material that the language itself conveys into a relatively complete knowledge system, namely to play the role of cognition as a background (Fauconnier, G., 1999). "The cognitive space based on the conceptual metaphor system of two cultures is the foundation of the translatability of metaphors, as well as the cognitive space where various translation strategies take functions (Tan Ye'sheng, 2006: p62). The following two examples are discussed in detail to illustrate the different concept mappings in Chinese and English culture.

Eg. (16): But no! His courage seemed suddenly to stiffen of its own accord.

$\mathrm{T} 1$ : 可是不行！他的勇气似乎突然自发地坚强起来。

TL: But no! His courage seemed to be suddenly strong of its own accord.

T2: 不, 不成！他的勇气突然涌现。

TL: No, no! His courage suddenly emerged.

T1 of Eg. (16) uses the inanimate subject “他的勇气, his courage” and the predicate “变坚硬, stiffen” and tries to keep the rhetorical device of personalization as the original text by collocation of “他的勇气, his courage” and “坚强 起来, to be strong-willed”. However, as a good quality of human being, “坚强起来, to be strong-willed” cannot be matched with the inanimate subject. T2 also remains the inanimate subject “他的勇气, his courage”, which is metaphorized as liquid and paired with the predicate “涌现, emerge". But in Chinese, “涌现, emerge" is often used to describe a certain kind of person, entity or work, see Eg. (3) (4). In Chinese, personal subjects are often used to describe people's spiritual temperament, etc directly. “勇 (yǒng)气 (qi), (to have) courage" metaphorizes the quality of courage as a substance of gas (as Chinese character “气 ( i) " means gas in English). The Chinese translation of Eg. (16) can be “他 (tā) 突 (tū) 然 (rán) 鼓 (gǔ) 起(qû)了 (le)勇 (yǒng)气 (qì) He suddenly plucked up courage”.

Eg.(3): 翻译作品大量涌现, 理论研究工作有所开展。 (《儿童文学概论》，1982）

LT: A large number of translated works have emerged and theoretical research has been carried out. (Introduction of Children's Literature, 1982)

Eg.(4): 这一时期各行各业涌现出大批具有劳动模范 和先进工作者。（《当代中国的人口》，1988）

LT: During this period, a large number of model workers and advanced workers emerged in all walks of life. (Population in Contemporary China, 1988)

Eg. (17): A faint smile twitched the corners of O'Brien's mouth as he looked down at him.

$\mathrm{T} 1$ ：奥博良低头看着温斯顿，嘴角上飘起一丝嘲意。

LT: O 'brien looked down at Winston, in the corners of his mouth a trace of irony floated.

$\mathrm{T} 2$ : 奥布赖恩嘴角露出浅浅的笑意, 俯下头来看着他。

LT: O'Brien in the corners of his mouth reveals light smile and looked down at him.

As for the metaphor of "smile", the research of Chen Shui'sheng (2017) shows that in the sentence construction of "smile" in English, "s mile" often functions as the subject, and the verbs paired with "smile" mostly reflect the metaphors of "action" and "force". In Chinese, the sentence construction of “微笑, smile” usually takes "human body" as the subject, and the verb mostly reflects the metaphor of "smile is an ornament or liquid", highlighting the emotional representation function of "smile". For example (17), the collocation of the subject "smile" and the predicate "(twitch, 急拉)" describes smiling as a force. The Chinese translation of this example cannot express the metaphorical effect of "s mile is power". In T1 and T2, the mouth, a part of the human body, is taken as the subject, and the use of the predicate verbs “飘起, float" and “露出, reveal" both reflect the metaphor of "smile is a liquid" in Chinese.

\section{Conclusions}

This case study analyzes the translation of Conceptual Metaphorical ESWIS in the novel 1984 from the perspective of conceptual metaphor theory. The major two findings are as follows: firstly, the universal existence of inanimate subjects in English and Chinese can be exp lained by direct description and metaphorization; secondly, due to the differences in conscious tendencies of the relationship between human beings and objects, as well as the differences in metaphorical using, the translation of Conceptual Metaphorical ESWIS may use the inanimate subject, or not, and then using the same or different conceptual metaphor, or transfer the metaphor into direct description.

The translation of ESWIS and metaphor as an important factor affecting the fluency and readability often confuses translator, not to mention the translation of Conceptual Metaphorical ESWIS. This paper is meant to provide practical and theoretical references for translation of ESWIS and metaphor translation as well and to help improve the culture communication between Chinese and English-speakers. 
This is a case study on English-Chinese literary translation, all the assumptions and finding are limited to literary translation. In addition, because of the length of the paper, this paper only takes Conceptual Metaphorical ESWIS - one the two types of Metaphorical ESWIS as the research object and researches on the Grammatical Metaphorical ESWIS are expected to be conducted.

\section{Funding}

The paper is funded by ECUST Projects: ZP1823105; P.80222301901001; P.50222361903001 and YS0125322.

\section{REFERENCES}

[1] Chen Shui'sheng, Corpus-based Comparison and Translation Study of Verbal Metaphors in English and Chinese -- A Case Study of the "Smile" Construction and the Relevant Translation of Ulysses, Shanghai Journal of Translators, No.4, 75-79,2017.

[2] Fauconnier, G. Introduction to Methods and Generalizations[A]. Cognitive Linguistics: Foundations, Scope and Methodology[C]. Eds. T. Janssen and G. Redeker Cognitive Linguistics Research Series 15. The Hague: Walter De Gruyter, 1999.

[3] Halliday. M. A. K. An Introduction to Functional Grammar, Edward Arnold, London, 1985 /1994.

[4] He Mingzhu. Type Analysis of Vitality and English Sentences with Inanimate Subjects, Journal of Xiangtan Normal University (Social Science Edition), Vol. 27, No.4:87-90, 2005.

[5] He Mingzhu. Comprehension and Translation of English Sentences with Inanimate subjects, Foreign Language Education, Vol. 24, No.5:51-55, 2003.

[6] He Mingzhu. Study Review of English Sentences with Inanimate Subject, Journal of Xi' an International Studies University, Vol. 19, No.2:10-13, 2011.

[7] Lakoff, G. \& Mark, J. Metaphors We Live by, The University of Chicago Press, Chicago, 1980.

[8] Lakoff, G. The Contemporary Theory of Metaphor [G] // A Ortony. Metaphor and Thought (2nd ed.), Cambridge University Press, Cambridge, 1992.

[9] Levin, B. English Verb Classes and Alternations: A Preliminary Investigation, The University of Chicago Press, Chicago, 1993.

[10] Sun Rui. Cognitive Interpretation of the Rhetorical Features of English Sentences with Inanimate Subjects, Journal of Hunan Agricultural University (Social Sciences), Vol 9. No.1: 97-99, 2008.

[11] Sun Xingwen. Metaphorical English Sentences with Inanimate Subjects: Life Characteristics and Translation Strategies, Journal of Yun'nan Normal University (Social Science Edition), Vol. 38, No.6: 125-130, 2006.
[12] Tan Ye'sheng \& Ge Jinrong. Cognitive Limitations of Metaphor Translation and Cognitive Space of Translation, Journal of PLA University of Foreign Languages, Vol. 28, No.4:59-63, 2005.

[13] Tan Ye'sheng. On Metaphorical Coherence in Fiction Translation -- Taking the Translation of FIRE Metaphors as an Example, Foreign Language Education, Vol 28, No.6:81-84, 2007.

[14] Wang De'chun. On metaphor -- Record for Doctoral Students in Linguistics, Foreign Language Research, No.1: 26-29, 2009.

[15] Wang Jianguo \& Zhang Hong. On "fluency" as the translation strategy prior to "faithfulness" (Foreign Studies, Vol 4, No.3:80-88, 2016.

[16] Wang Yin, Cognitive Linguistics, Shanghai Foreign Language Education Press, Shanghai, 2006.

[17] Weng Yi'ming. Analysis on English Sentence with Inanimate Subject with Functional Grammar, Journal of Sichuan International Studies University. Vol. 21, No.1, 87-89, 2005. 